V.E. Kosyakov

Features of Donald Trump's

Presidential Campaign

The image technologies of the US President Donald Trump during the presidential election of 2016 are analyzed. The principles of speechwriting, target audience and getting mass media attention as a source of free political advertising are considered.

Key words and word-combinations: Trump, presidential election of 2016, PR technologies, mass media.

Анализируются технологии построения имиджа президента США Д. Трампа в условиях предвыборной кампании 2016 г. Рассматриваются принципы построения выступлений, целевая аудитория и методика привлечения внимания СМИ как средства обеспечения политической рекламы.

Ключевые слова и словосочетания: Трамп, президентские выборы 2016, PR-технологии, CMИ.
DOI 10.22394/1682-2358-2017-1-105-111

УАK 324

ББК 66.3(0),131

\section{B.E. Косяков}

\section{ОСОБЕННОСТИ}

ИЗБИРАТЕАЬНОЙ

КАМПАНИИ А. ТРАМПА<smiles>[AlH2]</smiles>

збирательная кампания Аональда Трампа, как и сама его мичность, нетипичны Аля преАвыборной кампании среАнестатического политика, участвующего в президентских выборах. Процессы, происходившие в течение предвыборной гонки 2016 г. в США, следовано бы преАставить как раздувание целого ряда максимально возможных скандалов, которые, однако, вместо того, чтобы похоронить политическую карьеру столь необычного претендента на пост главы государства, позволици ему занять пост 45-го президента Соединенных Штатов Америки. Учитывая преАстоящие в 2018 г. президентские выборы в России, представляется полезным изучение и всесторонний анализ данной стратегии, с которой существует вероятность столкнуться.

Характеристикой избирательной кампании $\Lambda$. Трампа вполне могло бы стать его собственное выражение: «Самый большой успех приходит тогда, когда плывешь против течения» [1, с. 351]. Во многом имиджк А. Трампа построен на контркультуре и противопоставлении себя Аругим кандидатам. Манера поведения, провокационность заявлений, использование нелицеприятных, а иногда и откровенно грубых выражений нетипичны дия кандидата, участвующего в президентских выборах как в США, так и в России. Если следовать классификации 
типов политических мидеров [2, с. 86], то последовательно построенный на основе ряда перформансов [2, с. 84] имидж А. Трампа, который в течение всего предвыборного периода критиковал действующую власть, обвиняя остальных политиков в глупости, стремясь выгодно отличиться на их фоне и привлечь к себе внимание максимально возможной аудитории [3], соответствует типажу мидера-радикала, явцяющегося приверженцем среАств, которые дают мгновенный результат. Важной особенностью его предвыборной стратегии стало и то, что политик постоянно подчеркивал свою бцизость с народом, заявцяя, что видит все те же пробцемы, что и простые граждане. При этом отметим, что А. Трамп общался с абсолютно разными Аюдьми - от мимАиардеров и политиков до консьержей и обслуживающего персонала.

Время показало, что президентская кампания $\Lambda$. Трампа оказалась весьма эффективна, а первым вестником успешности его стратегии в начале предвыборной гонки стало то, что он оказался единственным кандидатом, которого узнали все опрошенные [4]. Исследование, проведенное A. Сайдсом [5] при помощи политических инструментов, предоставленных Grimson Hexagon, показало, что чем больше в новостных сюжетах удемяется внимания тому или иному кандидату, тем быстрее растет его рейтинг. Аогично предположить, что чем больше человек наблюдает кого-либо из поцитиков в СМИ, тем вероятнее он уже цеменаправленно заинтересуется его мичностью, а затем и деятельностью, и в случае отсутствия принципиальных разногласий с его идеями за него и проголосует. А. Трамп, по-видимому, своей приоритетной целью в агитационный период определил доминирование в медиапространстве и нахождение отклика в душе среднестатистического американца.

Предвыборная кампания и создание имиджа А. Трампа как претендента на президентский пост базировались на ряде приемов.

Во-первых, критика оппонентов. Так, СМИ в своей деятельности широко используют свойство человеческого сознания острее реагировать на негативную информацию и фиксирование ее в памяти. Газеты, радио и Интернет в первую очередь стараются осветить происшествия и скандалы. Именно этой не слишком этически чистоплотной, но гарантированно привлекающей внимание особенностью конџепџии работы современного медиапространства А. Трамп активно пользовался в построении своего имиАжа - противника внутренней и внешней политики, проводимой действующим на тот момент правительством США. Жесткая критика и даже нападки на оппонентов приносили ему, против ожиАаний, рост рейтинга. Например, 18 июля 2015 г. А. Трамп допустил ряд крайне резких высказываний в аАрес сенатора от штата Аризона, кандидата в президенты США 2010 г. А. МакКейна. $\Lambda$. Трамп заявиц, что $\Lambda$. МакКейн не может претендовать на статус героя войны цишь на том основании, что провец в плену более пяти мет [6]. Аанное высказывание, естественно, широко освещалось в новостях. ОАнако, несмотря на негативный окрас Аанного новостного сообщения, рейтинг $\triangle$. Трампа среАи республиканџев вырос за три дня на три пункта. 
Аругим объектом его нападок стал действующий на тот момент презиАент США Б. Обама, которого А. Трамп обвиния в некомпетентности [7]. Подобная тактика способствоваца росту рейтинга самого $А$. Трампа, что мишь подтвердило положение исследования А. Сайда о корреляџии эфирного времени и рейтинга кандидата: чем больше обсуждается кичность политика, тем выше его рейтинг, а эфир мегче всего занять яркому претенденту, который не стесняется жестко критиковать оппонентов, иногАа Аоходя АО крайностей.

В-вторых, знание своей аудитории. Трамп воспользовался знанием своей целевой аудитории (Аостаточно долгое время будущий 45-й президент США занимался продюсированием ряда телевизионных реалити-шоу) и работал цеменаправленно именно с ее проблемами. Среднестатистический сторонник А. Трампа в период его избирательной кампании - это белый мужчина в возрасте около 50 цет с Аоходом менее $\$ 50000$ в гоА, то есть меньше среАнегодового дохода житемя США, без высшего образования, консерватор. Такой человек больше всего интересуется темами иммиграции, зАравоохранения, экономики, а точнее, уровнем жизни в общем и уровнем доходов в частности. Аозунг А. Трампа "САелаем Америку вновь великой», удачно играющий на ностальгических и империалистических чувствах американцев, подошел такой аудитории как нельзя кстати. Обещания $А$. Трампа построить стену на границе с Мексикой, выгнав при этом незаконных мигрантов, отменить «Обамакер» и создать рабочие места относицись к сферам миграџии, здравоохранения и экономики соответственно, то есть именно к тем вопросам, которые и волновали его потенџиальных сторонников больше всего.

В-третьих, максимально упроченная речь и подача информачии. Согласно докмаду «Анализ удобочитаемости предвыборных речей президентской кампании США 2016 года» исследователей из Института языковых технологий Университета Карнеги-Мемлон, речь А. Трампа соответствует уровню речи школьника возраста 11 мет. Язык 69-летнего бизнесмена уступает языку его соперников: и ТеА Круз, и Марко Рубио использовали грамматику, соответствующую возрасту 11-14 九ет, а их словарный запас был более продвинутым как у учащихся в возрасте 13-16 ^ет [8] .

Анализируя его речь о терроризме, можно отметить следующие закономерности: в своем минутном ответе на вопрос о допустимости притеснения мюдей мишь на основе религиозного фактора А. Трамп каждое свое преАможение заканчивал на высокой ноте. Из 220 слов каждое двадџатое несло негативный оттенок вреда, вражды, смерти и прочих понятий, четко зафиксированных в человеческом сознании как отриџательные. В речи о теракте в Париже четыре предложения подряА были построены абсолютно идентично. Тем самым А. Трамп, используя старый метод повторения одной и той же информации многократно, снабдив ее эмоџиональной составмяющей, стремился подвести зрителя к выводу, что мир полон вражды, а ислам особенно враждебен по отношению к США, и с этой враждебностью нужно бороться. Свой ответ $A$. Трамп также закончия на высокой ноте, в двух предложкениях 
подряд упомянув свое имя в третьем мице в связке со словами «проблема», «помощь», «понимание», стремясь закрепить ассоџиативный ряд «Трамп решение проблемы».

В-четвертых, әбусмисленность речей. Так, речи А. Трампа зачастую намеренно содержкали противоречия и взаимоискцючающие пункты. ОАним из таких ярких примеров стала его речь, в которой он заявиц, что намерен в случае своего избрания увекичить финансирование армии, однако далее отметиц, что не хочет эту армию использовать. Не менее противоречивым явцялось и утверждение теперь уже прошеАшего инаугурацию президента о том, что США не Аолжны заниматься строительством наџий, но внешняя политика государства Аолжна быть направлена на укрепление региональной стабильности [9] . Подобным способом достигалось желаемое пристальное внимание СМИ, представители которых как бы подлавливали политика на таких «ошибках», уделяя ему все больше эфирного времени. Кроме того, таким приемом обеспечивалось и двоякость восприятия аудиторией: каждый мог толковать слова кандидата по своему усмотрению.

В-пятых, максимально громкие и резкие заявления, предлагаюиие радикальноге пути решения проблем. В течение всей президентской гонки $А$. Трамп преподносил свои предложения как смелые и бескомпромиссные, которые мюбой Аругой побоялся бы даже просто озвучить.

Предвыборную программу $А$. Трампа условно можно разделить на несколько категорий: решение проблемы миграционной политики; реформа зАравоохранения; оптимизация экономической политики; борьба с терроризмом.

Реализация мероприятий в области миграционной политики, по $А$. Трампу, Аолжна была привести к ослаблению, а в дальнейшем и прекращению притока мигрантов из Мексики, а также потенциальных преступников и террористов из Аругих стран. А. Трамп обосновывац необходимость укрепмения государственных границ, напрямую обвиняя нелегамьных мигрантовмексиканцев в криминале, торговле наркотиками и изнасилованиях [10], заявцяя в ответ на упрек в безосновательности подобных утверждений: «Если бы меня не было, вы бы вообще не говорили о нелегальной иммиграции» [11], продолжая тем самым формирование образа смелого и бескомпромиссного политика.

Продолжая идти по пути неординарных решений, А. Трамп утверждал, что планирует остановить поток выходџев из Аатинской Америки путем строительства стены на границе с Мексикой, причем за счет среАств послеАней. Способ заставить южкных соседей выполнить столь категоричные требования политик изыскац также нестандартный: в случае бойкотирования ультиматума - введение государственного запрета на денежные переводы Аля мексиканцев, работающих в США. Заявление громкое, жесткое, слегка отдающее наивностью, но именно поэтому мегко запоминающееся, что в тот момент и требовалось.

Миграционные проблемы, по А. Трампу, Мексикой не ограничиваются, мигранты приезжают и из других стран Аатинской Америки и БАижнего 
Востока. В разговоре о религии и терроризме кандидат-республиканец заявил, что ислам ненавидит американцев [12], смягчив, правАа, столь категоричное утверждение, пояснив, что сегодня тяжело отличить обычных исламистов от радикальных. Решение было предложено уже ожидаемо бескомпромиссное: превентивно запретить въезА на территорию США мусульманам, мицам из исмамских и мюбых Аругих стран, граждане которых совершали теракты против насемения США и Евросоюза.

Позиция $\Lambda$. Трампа по поводу здравоохранения также отличалась непримиримостью. Политик заявиц, что намерен в случае избрания президентом отказаться от «Обамакер» (реформы зАравоохранения, введенной действующим на тот момент президентом США Б. Обамой, главным эмементом которой явмяется всеобщее обязательное медицинское страхование) и найти альтернативное решение, менее обременительное в финансовом смысме и дмя граждан, и дмя государства [4]. Ненавязчиво демонстрируя, что понимает затруднения малоимущих слоев населения по выплате страховых взносов (в среднем, \$278 на человека), А. Трамп предложиц как вариант вернуть в полном объеме программы «Медикер» (наџиональная программа медиџинского страхования пожилых мюдей и инвалидов) и "МедикейА» (программа медицинской помощи семьям с уровнем достатка ниже черты бедности, финансируется на уровне штатов при подАержке федеральных властей). Таким образом, выступая оппонентом действуюшего президента США, А. Трамп демонстрировал решительный настрой действовать в интересах простого народа.

Как претендент на пост главы государства, $А$. Трамп не мог обойти в своих предвыборных заявлениях и собственное видение решения экономических проблем страны, к которым в первую очередь относится высокий уровень безработиџы в США, по оџенкам рабочей группы А. Трампа составмявший 21\% на середину 2015 г. Новые рабочие места политик предложил создавать за счет возвращения американского бизнеса из-за граниџы. По его словам, введение высоких пошлин дяя американских компаний, чьи заводы находятся за рубежом, вынудит их вернуть производство на территорию США [4] . Вполне очевидно, что риторика А. Трампа в очередной раз была направлена на Аемонстрацию его готовности иАти против политической и экономической эмиты страны в интересах рядового американского гражданина.

К сожалению для А. Трампа, не всегда его слишком громкие заявления шли на пользу рейтингу: притягивая одобрительное согласие одних групп общества, он настраивац против себя другие слои насемения в миџе женщин, мусульман, мигрантов из Мексики, Аибералов, что неоднократно приводило не просто к снижению рейтингов, но почти к провалу, недаром его кандидатура многими даже не рассматривахась всерьез [13]. Например, А. Трамп не только не получил поддержки у тех американџев, чьи родственники жили или живут в Аатинском Америке (по статистике на 2014 г. матиноамериканцы составляли 17\% населения, а белое население - 62\% [14]), но и вызвал их решительные протесты, о чем свидетельствуют погромы, прошедшие по стране уже после инаугурации президента. 
Кроме того, А. Трамп настроиц против себя около $70 \%$ женского электората, заявив, что женщины, сделавшие аборт, должны понести наказание, что было расценено как нарушение права женщин распоряжаться собственным телом. В свою очередь, противники абортов высказали резкое недовольство намерением $А$. Трампа наказывать за них женщин. Традиџионно активисты, выступающие против абортов, призывают возмагать ответственность не на женщин, а на врачей, которые проводят операцию. Позже $А$. Трамп постарался переформулировать свою мысль с целью сгладить углы: «Врач или мю-

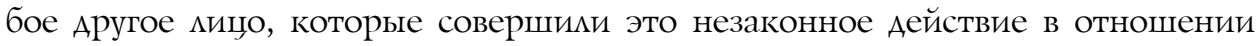
женщины, должны нести юридическую ответственность, а не женщина». Он Аобавиц, что в этом случае женщина, равно как и жизнь в ее утробе, явцяется жертвой [15] .

$\triangle$ аже поверхностный анализ президентской кампании $\Lambda$. Трампа показывает, что его стратегия оказалась парадоксально успешной. Пока неизвестно, каким будет правление нового президента США, хотя он продолжает противопоставлять себя уже сложившему полномочия Б. Обаме, заморозив одобренный последним транш для Палестины, и планирует претворить в жизнь свое намерение построить стену с Мексикой. Остается добавить, что утверждение на этот государственный пост явицось одним из тех реАких случаев, когда кандидат проигрывает по обшему количеству голосов, но окончательно выигрывает, получив большинство голосов коммегии выборщиков.

Тактика регулярного провоџирования скандалов, слеАствием которых неизменно становимось привлечение внимания общественности и фиксация в сознании потенциамьной цемевой аудитории кегко узнаваемого образа; нарочитая простота речи и звучность мозунгов; цеменаправленные действия, направленные на уничтожение имиджа оппонента, отличное знание законодательства американского государства и системы проведения выборов в ней - вот составмяющие успешности и эффективности преАвыборной кампании ныне действующего 45-го президента США.

\section{Библиографический список}

1. Trump D.J., Zanker B. Think Big and Kick Ass in Business and Life. HarperLuxe, 2007.

2. Аржсанова K.A. Социально-механические механизмы формирования имиджа политического лидера в процессе избирательной кампании: дис. ... канд. психол. наук. М., 2015.

3. Boyer D. Trupm says 'our politicans are stupid', calls for wall to keep out Mexicans // The Washington Post. 2015. Sept. 29. URL: http://www.washingtontimes.com/news/2015/aug/6/donaldtrump-says-our-politicians-are-stupid-calls/

4. Дергачев $C$. В Белый дом на золотом эскалаторе: особенности предвыборной кампании Дональда Трампа. URL: https://lenta.ru/articles/2015/06/25/donald_trump/

5. Sides J. Why is Donald Trump declining in the polls? The media strike again// The Washington Post. 2015. Sept. 29. URL: https://www.washingtonpost.com/blogs/monkey-cage/wp/2015/09/29/ why-is-donald-trump-declining-in-the-polls-the-media-strike-again/

6. Schreckinger B. Trump attacks McCain: 'I like people who weren't captured'// Politico. 2015. July 18. URL: http://www.politico.com/story/2015/07/trump-attacks-mccain-i-like-people-whowerent-captured-120317\#ixzz4D4NbkujF 
7. Corcoran K. 'I would say Obama's incompetent... but that's not nice': Round-up of the best GOP debate one-liners // Dailymail. 2015. Aug. 7. URL: http://www.dailymail.co.uk/news/article3187655/I-say-Obama-s-incompetent-s-not-nice-Republican-candidates-let-rip-slew-debate-oneliners.html

8. Spice B. Most Presidential Candidates Speak at Grade 6-8 Level // Carnegie Mellon University. 2016. March 16. URL: https://www.cmu.edu/news/stories/archives/2016/march/speechifying.html

9. Трамп рассказал о своей экономической программе. URL: https://ria.ru/world/20160808/ 1473887264.html

10. Ye Hee Lee M. Donald Trump's false comments connecting Mexican immigrants and crime // The Washington Post. 2015. July 8. URL: https://www.washingtonpost.com/news/fact-checker/ wp/2015/07/08/donald-trumps-false-comments-connecting-mexican-immigrants-and-crime/

11. O'Reilly A. At GOP debate, Trump says 'stupid' U.S. leaders are being duped by Mexico // Foxnews. 2015. Aug. 6. URL: http://latino.foxnews.com/latino/politics/2015/08/06/at-republicandebate-trump-says-mexico-is-sending-criminals-because-us/

12. Schleifer T. Donald Trump: 'I think Islam hates us' // CNN politics. 2016. March 10. URL: http://edition.cnn.com/2016/03/09/politics/donald-trump-islam-hates-us/

13. General Election: Trump vs. Clinton // RealClear Politics. URL: http://www.realclearpolitics. com/epolls/2016/president/us/general_election_trump_vs_clinton-5491.html

14. Percentage of population in the United States in 2014 and 2060, by race and Hispanic origin // The Statistics Portal. URL: https://www.statista.com/statistics/270272/percentage-of-uspopulation-by-ethnicities/

15. Cirilli K. Trump Reverses on Abortion Ban, Saying Doctors, Not Women, Would Be Punished // Bloomberg Politics. 2016. March 31. URL: http://www.bloomberg.com/politics/articles/2016-03-30/trump-says-abortion-ban-should-carry-punishment-for-women 